\title{
Glandular (Acinar)/Tubular Differentiation Score
}

National Cancer Institute

\section{Source}

National Cancer Institute. Glandular (Acinar)/T ubular Differentiation Score. NCI

Thesaurus. Code C138974.

A score assigned to a biopsy sample indicating the relative amount of cells with glandular differentiation. 